\title{
Problems in Accounting Calculation of Small and Medium Enterprises and Suggested Countermeasures
}

\author{
Ai Xueying \\ Taihe Hospital in Shiyan, China, 442000
}

Keywords: Small and Medium Enterprises; Accounting; Suggestions

\begin{abstract}
With the rapid development of China's economy, the scale and number of small and medium-sized enterprises have increased year by year, making the competition among small and medium-sized enterprises in the market very fierce. Scientific and reasonable accounting is the key to an enterprise's competitive advantage, which can help enterprises realize value and production cost advantages. However, due to the influence of traditional concepts, small and medium-sized enterprises still have many problems in accounting, which is not conducive to enterprises to obtain profits. Therefore, enterprises should pay attention to the control of accounting and improve the economic efficiency of enterprises. Based on this, this paper analyzes the problems existing in the accounting of small and medium-sized enterprises, and proposes effective solutions to promote long-term and healthy development of enterprises.
\end{abstract}

\section{Introduction}

For small and medium-sized enterprises, accounting is a very important part. Moreover, due to the current development of China's market economy, the development of small and medium-sized enterprises in this period has naturally become a very important force in China's economic development (Joachim, 2018). Therefore, it is very important to do a good job in accounting for small and medium-sized enterprises (Langton, 2018). It is not only about the internal economics of a company, but also about the future of the company and even the future (Khalid, 2018). Only by doing a good job in accounting and perfecting various mechanisms can we finally enable small and medium-sized enterprises to better develop continuously and contribute to the overall economic development of the country (Lynda, 2018).

\section{Problems in accounting of small and medium-sized enterprises}

\subsection{The subject of accounting is unclear}

Generally, the production and operation process of small and medium-sized enterprises is relatively simple, mainly in the procurement of raw materials, design, processing, sales, and production, and production of various products according to market and customer requirements (Nihel, 2018). In the sales process, in addition to a small amount in the company's own stores, the sales share is still completed through distribution. This type of operation is mainly through the use 
of order-based production and distribution models through the use of power-sellers (Meredith, 2018). When the loan is settled, it is mainly carried out in cash. The entire procurement process is usually 60 days. After the time is up, the cash is settled, and then the company conducts accounting. However, with the gradual expansion of the scale of enterprises, shareholders have created certain contradictions and frictions due to differences in interests and decision-making concepts (Khalid, 2018). At the same time, due to the internal friction of the company's department to maximize the interests of the narrow department, it is inevitable that the financial department will have some friction, so that the company's financial workers are often forced to meet the surface high efficiency of certain departments from the book (Alina, 2018). At the same time, due to the lack of effective management, cashiers have used cash receipts for corruption. The cashier will receive the cash received into his own pockets and then give customers a certain discount by issuing a receipt. In this way, due to the unclear boundary of the accounting entity, the problems of system and management are gradually exposed, which seriously affects the sustainable and stable development of the enterprise.

\subsection{Generally do not pay attention to accounting work}

The management methods of small and medium-sized enterprises are generally extensive management. They do not pay much attention to accounting work, and then the accounting personnel are not paid attention to. Therefore, the turnover rate of workers in enterprises is also large. The accounting and finance work of a small and medium-sized enterprise is generally the responsibility of a vice president in charge of finance. However, as the scale of the enterprise continues to expand, its lack of professional knowledge gradually shows its drawbacks, but the company does not attach importance to its accounting. Training education only follows the previous accounting management philosophy. Although the company's old accounting staff with many years of work experience can handle the specific accounting and financial accounting problems, it does not have a modern accounting and financial management concept, which makes the company lack a scientific and systematic accounting and finance from top to bottom. Management ideas and patterns. At present, some enterprises are not fully aware of the important role of conducting enterprise accounting.

\subsection{Weak accounting work}

In order to ensure the continuity of the production and operation process, enterprises must purchase and sell inventories in a planned manner, which will become an important asset in the production and operation process, and also a favorable guarantee for ensuring the smooth operation of production and operation activities. It can be directly reflected from the importance attached to the inventory management and the quality of management. Facts have proved that the control and management of inventory will make it possible for enterprises on the verge of extinction to have a life-returning effect. Otherwise, enterprises will be faced with difficulties. For a long time, the foundation is weak and the starting point is low. The uncompleted and perfect internal management system is a common phenomenon in the management of small and medium-sized enterprises. The importance of enterprise inventory control and management has not been realized in the production and operation process. In view of the small number of private SMEs and the multiple roles of the management department, the lack of professional forecasting and effective control over the key aspects of production and sales, basically one person has the final say, complete the purchase and sales, payment collection and handling. The whole process of library procedures. Procurement without control, unsupervised sales, lost inventory, serious loss, and inconsistent accounts, exist in many small and medium-sized enterprises, which reflects that the ratio of inventory to current assets 
is too high, the inventory turnover rate is slowing, and the losses caused to enterprises are Unable to estimate. It is thus known that inventory management has a significant impact on the survival and development of enterprises.

\subsection{The establishment of accounting institutions and the appointment of corporate accountants do not meet the requirements of accounting standards}

The accounting staff of small and medium-sized enterprises often bear the overloaded work, the post setting has no laws to avoid risks, does not consider the mutual supervision of posts, and emphasizes the workload of accounting personnel and neglects the development and training of accounting personnel skills, thus making financial personnel The skills cannot be improved. At the same time, low-quality accounting managers lack the deep-seated active management management issues and interests. At present, the accounting supervision work of many enterprises is not in place, and the functions of enterprise accounting work are weakened. There are illegal factors in the accounting work of many enterprises, which are closely related to the insufficiency of accounting supervision of enterprises. Only by doing a good job in accounting supervision of enterprises can we better guarantee the property of the company. The professional ability and comprehensive quality of enterprise accounting staff have a very important impact on the quality of enterprise accounting work. Only when their professional ability and comprehensive quality can meet the relevant standards, can the high-quality completion of enterprise accounting work, so that all the work of the enterprise can be carried out reasonably.

\section{Solving the problems in the accounting of small and medium-sized enterprises}

\subsection{Establish an accounting system that is compatible with small and medium-sized enterprises as soon as possible}

Small and medium-sized enterprises should, while improving the consciousness of accounting management, dare to break through the family-style and traditional management consciousness and management methods, and dare to adopt advanced and reasonable management methods. In the process of constructing a new accounting management system, enterprises should rationally use network technology and ERP systems for scientific management in the context of corporate funds and staff capacity conditions. And with this supporting the establishment of the corresponding management system and operational specifications. Thereby achieving the scientific and orderly work of accounting management related work. Whether it is the basic accounting workflow or the later audit work, it can be scientific and orderly. It not only makes the specific work have scientific operational norms, but also promotes the mutual cooperation between the internal departments of the enterprise and clarifies the division of labor and responsibilities, thus promoting the orderly conduct of the company's accounting management. At the same time, it can also form more scientific and complete financial information, which can not only provide reference for corporate decision-making, but also provide a basis for future loans to financial institutions. Conversely, when the company's own conditions are very limited, it is impossible to fully implement the computerized working conditions, or the accounting department staff can not quickly adapt to the conditions of computerization. Business decision makers should improve the status quo by introducing a "public accounting director”. 


\subsection{Strengthen the education of the legal concept and improve the quality of accounting personnel}

In view of the current lack of understanding of accounting work in many enterprises, we must strengthen learning and raise awareness of the importance of corporate financial management. Only by doing a good job in financial management of enterprises can the enterprise adapt to the current complex economic situation. The management personnel of the enterprise must allocate the funds of the enterprise reasonably, and minimize the interference in the accounting work of enterprises. When the enterprise accounting staff work It must be carried out in strict accordance with the law, so that the enterprise accounting work can be carried out smoothly, and the role can be fully exerted, thus bringing greater economic benefits to small and medium-sized enterprises.

For small and medium-sized enterprises, the important influence of whether the accounting management function can be effectively realized is the professional quality of its accounting staff. Even with the most scientific accounting management system and the most advanced hardware support, if you leave the senior management with advanced management concepts and a stable high-quality accountant team, it will become empty talk to achieve efficient management. Reasonable setting of accounting positions, avoiding risks, and establishing mutual restraint and supervision between positions, thus greatly reducing the risk of fraud that the company may face.

\subsection{Strengthen the basic work of accounting and improve the quality of accounting work}

The globalization of the economy has greatly increased the competitive pressure faced by small and medium-sized enterprises. If it is managed according to the original business philosophy, the development of the enterprise will be difficult. For the majority of small and medium-sized enterprises in China, only by correctly analyzing and forecasting according to the actual accounting data, and carrying out scientific management and giving full play to the effective functions of accounting management, can we win the proper position in the fierce confrontation between enterprises in the future. . However, a large number of small and medium-sized enterprises in China have poor management of accounting management, especially the lack of standardization of fund management, confusion of accounting and inventory management, and serious interference with decision analysis, which seriously hinders the normal development of enterprises. If small and medium-sized enterprises are to be based in the industry, strengthen the basic work of accounting and strengthen the management of cost control links such as procurement, sales and inventory, so as to achieve the goal of saving cost and enhancing competitiveness.

\subsection{Increase external supervision and inspection efforts}

In view of the safety of its own credit funds, banks are proposing to provide loan guarantees and mortgages when lending to enterprises. The support of small and medium-sized enterprises in the guarantee institutions will help accelerate the bank loans. To this end, small and medium-sized enterprises should strive to improve their creditworthiness, and strive to improve their credit status in terms of returning loans, providing reliable guarantees, and increasing collateralized assets. Small and medium-sized enterprises should establish a risk control mechanism for accounting and increase external supervision and inspection. With the intensification of competition among enterprises, the subjective judgment of entrepreneurs is difficult to rationally manage enterprises. Therefore, SMEs should reduce the cost and reduce the pressure on the capital turnover of enterprises through the optimization of the procurement process. At the same time, measures should be taken to improve the efficiency of the use of working capital, thereby reducing the accounting and financial risks of enterprises. 


\section{Conclusions}

In short, as the situation faced by enterprises becomes more and more complicated, enterprises must do a good job in accounting according to their own circumstances, and provide timely and effective accounting information so that leaders can make decisions and enable the company's work to proceed smoothly. To make the company invincible.

\section{References}

[1] Joachim H. A. Krug. Accounting of GHG emissions and removals from forest management: a long road from Kyoto to Paris [J]. Carbon Balance and Management, 2018,13(1):27-36.

[2]Langton Mburayi,Tony Wall. Sustainability in the professional accounting and finance curriculum: an exploration [J]. Higher Education, Skills and Work-Based Learning,2018,8(3):78-82.

[3]Khalid A. Alanzi, Mishari M. Alfraih. The effect of students' performance in introductory accounting on college duration [J]. Journal of Global Responsibility,2018,9(3):14-21.

[4]Lynda C. Taylor. Reassessing and refining theory in qualitative accounting research [J]. Qualitative Research in Accounting \&amp; Management, 2018, 15(4):182-188.

[5]Nihel Chabrak. Reforming accounting to support the shift towards a sustainable financial system [J]. Journal of Capital Markets Studies, 2018,2(2):47-53.

[6]Meredith Tharapos, Brendan O'Connell,Steven Dellaportas,Ilias Basioudis. Are accounting academics culturally intelligent?: An empirical investigation[J]. The British Accounting Review, 2018, 14(1):76-89.

[7]Khalid A. Alanzi. Female accounting students and their academic performance: evidence from Kuwait [J]. Journal of Islamic Accounting and Business Research, 2018,9(5):112-119.

[8]Alina-Teodora Ciuhureanu. Study on Accounting Organization: Options and Influence Factors [J]. International conference KNOWLEDGE-BASED ORGANIZATION, 2018, 24(2):62-67. 